University of Nebraska - Lincoln

DigitalCommons@University of Nebraska - Lincoln

\title{
TRAIT CONVERGENCE AND PLASTICITY AMONG NATIVE AND INVASIVE SPECIES IN RESOURCE-POOR ENVIRONMENTS
}

Rebecca E. Drenovsky

John Carroll University, rdrenovsky@jcu.edu

Albina Khasanova

John Carroll University

Jeremy J. James

USDA-ARS Eastern Oregon RC, Burns, OR, jeremy.james@ars.usda.gov

Follow this and additional works at: https://digitalcommons.unl.edu/usdaarsfacpub

Part of the Agricultural Science Commons

Drenovsky, Rebecca E.; Khasanova, Albina; and James, Jeremy J., "TRAIT CONVERGENCE AND

PLASTICITY AMONG NATIVE AND INVASIVE SPECIES IN RESOURCE-POOR ENVIRONMENTS" (2012).

Publications from USDA-ARS / UNL Faculty. 826.

https://digitalcommons.unl.edu/usdaarsfacpub/826

This Article is brought to you for free and open access by the U.S. Department of Agriculture: Agricultural Research Service, Lincoln, Nebraska at DigitalCommons@University of Nebraska - Lincoln. It has been accepted for inclusion in Publications from USDA-ARS / UNL Faculty by an authorized administrator of DigitalCommons@University of Nebraska - Lincoln. 


\title{
TRAIT CONVERGENCE AND PLASTICITY AMONG NATIVE AND INVASIVE SPECIES IN RESOURCE-POOR ENVIRONMENTS ${ }^{1}$
}

\author{
Rebecca E. Drenovsky ${ }^{2,4}$, Albina Khasanova ${ }^{2}$, and Jeremy J. James ${ }^{3}$ \\ ${ }^{2}$ Biology Department, John Carroll University 20700 North Park Blvd., University Heights, Ohio 44118 USA; and ${ }^{3}$ USDA- \\ Agricultural Research Service, Eastern Oregon Agricultural Research Center 67826-A Hwy 205, Burns, Oregon 97720 USA
}

- Premise of study: Functional trait comparisons provide a framework with which to assess invasion and invasion resistance. However, recent studies have found evidence for both trait convergence and divergence among coexisting dominant native and invasive species. Few studies have assessed how multiple stresses constrain trait values and plasticity, and no study has included direct measurements of nutrient conservation traits, which are critical to plants growing in low-resource environments.

- Methods: We evaluated how nutrient and water stresses affect growth and allocation, water potential and gas exchange, and nitrogen $(\mathrm{N})$ allocation and use traits among a suite of six codominant species from the Intermountain West to determine trait values and plasticity. In the greenhouse, we grew our species under a full factorial combination of high and low $\mathrm{N}$ and water availability. We measured relative growth rate (RGR) and its components, total biomass, biomass allocation, midday water potential, photosynthetic rate, water-use efficiency (WUE), green leaf $\mathrm{N}$, senesced leaf $\mathrm{N}$, total $\mathrm{N}$ pools, $\mathrm{N}$ productivity, and photosynthetic $\mathrm{N}$ use efficiency.

- Key results: Overall, soil water availability constrained plant responses to $\mathrm{N}$ availability and was the major driver of plant trait variation in our analysis. Drought decreased plant biomass and RGR, limited N conservation, and led to increased WUE. For most traits, native and nonnative species were similarly plastic.

- Conclusions: Our data suggest native and invasive biomass dominants may converge on functionally similar traits and demonstrate comparable ability to respond to changes in resource availability.

Key words: forbs; gas exchange; Great Basin; knapweed; nitrogen; resorption proficiency.

Functional traits provide a valuable conceptual basis for describing variation in plant ecological strategies, the distribution and abundance of species, and mechanisms of coexistence and community assembly as well as for predicting ecological effects and responses of plant communities to their environment (Weiher and Keddy, 1999; Diaz and Cabido, 2001; Lavorel and Garnier, 2002; Suding et al., 2008). Alternative hypotheses about mechanisms of invasion and invasion resistance differ in their prediction of how functional traits and trait plasticity are expected to vary among native and invasive species. For example, hypotheses based on habitat filtering and neutral processes predict that invasive species and dominant native species should have similar functional trait values (Thompson et al., 1995; Duncan and Williams, 2002; Daleo et al., 2009). Alternatively, hypotheses based on limiting similarity between native and invasive species as well as hypotheses based on leaf and root tissue economics predict that invasive species and dominant native species should differ in their functional traits (Fargione et al., 2003; Funk 2008). Additionally, it has long been proposed that greater trait plasticity of invasive species compared with that of native species provides invasive species a fitness advantage under fluctuating environmental conditions (Baker, 1965). Thus, understanding functional trait convergence or divergence among native and invasive species as well as environmental

${ }^{1}$ Manuscript received 26 August 2011; revision accepted 18 January 2012.

The authors thank L. Ziegenhagen for laboratory and greenhouse assistance and two anonymous reviewers for helpful comments on the manuscript. A Summer Research Fellowship from John Carroll University (R.E.D.) helped support this work.

${ }^{4}$ Author for correspondence (e-mail: rdrenovsky @jcu.edu)

doi:10.3732/ajb.1100417 constraints on trait plasticity is a key step toward refining general hypotheses of invasion and invasion resistance. These mechanistic hypotheses, in turn, provide the ecological basis for predicting and managing plant invasions (James et al., 2010) as well as for improving our understanding of invader impacts on ecosystems.

Given the importance in understanding functional trait variation, a substantial amount of research has focused on describing differences in trait values and trait plasticity between native and invasive species. Recent quantitative syntheses of this literature have demonstrated several strong and important patterns of functional trait variation between native and invasive species. Community- and global-scale comparisons of native and invasive leaf traits as well as meta-analysis have demonstrated that invasive species tend to producer thinner and less dense leaves than native species, resulting in a higher specific leaf area (SLA) (Leishman et al., 2007; van Kleunen et al., 2010). With respect to carbon assimilation and allocation, a higher SLA allows invasive species to achieve a greater return on biomass invested in leaves and allows invasive species to achieve greater root and shoot growth rates than native species (Lambers and Poorter, 1992). Ultimately, these and other traits such as high leaf nutrient concentration and assimilation rates position invasive species further along the leaf economic spectrum toward an ecological strategy that favors resource capture over resource conservation (Wright et al., 2004; Leishman et al., 2010).

Recent meta-analysis and phylogenetically controlled comparisons also support the long-held notion that invasive species have greater trait plasticity than native species when resources increase (Funk, 2008; Davidson et al., 2011). However, some key examples run counter to these general trends. For example, broad-scale comparisons of trait differences between invasive and native species across contrasting climatic and land-use 
regimes suggest environmental filtering has led to similar distributions of functional traits between native and invasive herbaceous plants (Tecco et al., 2010). Likewise, a recent study found little evidence for differences in plasticity among native and invasive forbs (Scharfy et al., 2011). Previous studies that support increased plasticity of invasive over native species also suggest plasticity can vary depending on resource type and that plasticity may not necessarily confer a fitness advantage (Funk, 2008; Davidson et al., 2011). Key knowledge gaps limit our understanding of trait values and trait plasticity differences between native and invasive species, particularly in resource-poor environments.

First, it is unclear how multiple stresses influence differences in trait values and plasticity between native and invasive species. Recent meta-analysis and literature reviews indicate that most work on plasticity and trait values of native and invasive species has largely been based on single-resource manipulations (Richards et al., 2006; Davidson et al., 2011; but see Leishman and Thomson, 2005; Funk, 2008). Single-resource manipulations ignore the important ecological constraints that limit or alter the adaptive value of trait plasticity (Valladares et al., 2007). Specifically, in resource-poor environments, plant growth and plasticity often are limited by multiple abiotic stresses (Valladares and Pearcy, 2002). Thus, in these environments phenotypes that display a fitness advantage under manipulation of a single factor may be maladaptive or constrained when plants are exposed to other abiotic stressors (Valladares et al., 2007). We propose nutrient and drought stress, together, may have one of the strongest effects on differences in trait values and trait plasticity between native and invasive species. Invasion has long been tied to increases in nutrient availability (Huenneke et al., 1990; Thompson et al., 2001). However, invasive species recently have been found to be successful in both high- and low-nutrient soils (Funk and Vitousek, 2007). Their success has been linked to greater resource-use efficiency (e.g., Drenovsky et al., 2008) and to their ability to construct cheaper (less thick and dense) leaf and root tissue in both high- and lowfertility soils, providing invasive species an initial growth advantage (James et al., 2011). However, the rapid growth and size advantage that invasive species achieve through the construction of cheaper tissues comes at a cost in terms of decreased tissue life span and a reduced ability to maintain physiological function under drought stress (Dale and Causton, 1992; RamirezValiente et al., 2010; Scheepens et al., 2010). Construction of tougher tissues by native species can increase resource conservation by decreasing tissue loss due to abiotic and biotic stress and can allow native species to maintain growth as soils dry. Thus, while development of more expensive tissues may limit native plant plasticity in response to variation in nutrient availability, under drought stress it may allow native species to maintain greater fitness than invasive species.

Second, we know very little about variation and plasticity of resource conservation traits of native and invasive species. The bulk of comparative work has focused on traits related to resource capture, resource-use efficiency, growth, and biomass allocation (van Kleunen et al., 2010; Davidson et al., 2011). Resource conservation is influenced by traits such as SLA and resource-use efficiency. Lower SLA values generally increase leaf lifespan and therefore the duration of return on resource invested in leaves; likewise, greater resource-use efficiency means a plant can construct more biomass per unit of resource acquired (Wright et al., 2004; Funk and Vitousek, 2007). Although these traits have been studied in detail for native and invasive species for perennial plants, they influence only part of a plant's nutrient budget. The abilities to resorb nutrients from senescing tissues and to store these nutrients for future use in stem and root tissues are key nutrient conservation mechanisms for plants from low-nutrient environments (Killingbeck, 1996; Killingbeck and Whitford, 1996; van Heerwaarden et al., 2003). For native species, higher leaf nutrient resorption has been correlated with greater whole-plant nutrient retention and increased plant fitness (May and Killingbeck, 1992; Aerts, 1996). The patterns of resorption and storage between native and invasive species and the degree to which multiple environmental stresses influence plasticity in these traits have not been examined.

The broad objective of this study was to examine how the interactions of water and nutrient stress influence key growth, resource capture, and resource conservation traits as well as trait plasticity among codominant native and invasive species from the Intermountain West of the United States, where both water and nutrients colimit productivity. Under the expected trade-offs associated with tissue economics, we hypothesized that invasive species would have higher values for traits related to resource capture, utilization, and growth, whereas native species would show greater values for traits related to nutrient conservation. We predicted that nutrient conservation traits of native species coupled with construction of leaves with lower SLA would allow them to maintain greater biomass as nutrient and water availability simultaneously declined. In addition, on the basis of this expected trade-off between SLA and responses to changes in resources availability, we also predicted that invasive species would demonstrate a higher SLA and greater biomass plasticity in response to simultaneous changes in nutrient and water availability.

\section{MATERIALS AND METHODS}

Study species-The species selected included a suite of native grasses and forbs commonly used in restoration programs in the Intermountain West of the United States. The native perennial grasses included Elymus elymoides (bottlebrush squirreltail; Poaceae) and Pseudoroegneria spicata (bluebunch wheatgrass; Poaceae), and the native perennial forbs included Achillea millefolium (common yarrow; Asteraceae) and Sphaeralcea munroana (Munro's globemallow; Malvaceae). Their responses were compared with those of two key nonnative forbs, Centaurea stoebe (spotted knapweed; Asteraceae) and Linaria dalmatica (Dalmatian toadflax; Scrophulariaceae). Both nonnative species are listed as noxious weeds in the Intermountain West.

Experimental design-Seeds of the various species were germinated on filter paper, and then seedlings were transplanted into 12 -L pots filled with a $1: 2$ fritted clay to sandy field soil mix. Large pots were used to minimize plant effects on resource availability. Two weeks after production of first true leaves, the plants were randomly assigned to a factorial combination of one of two nitrogen $(\mathrm{N})$ treatments (high N: 2 g of slow release 10-10-10 NPK; low N: no fertilizer addition) and one of two water treatments (well watered vs. drought). At this time, six replicates of each species were harvested for determination of initial variables for relative growth rate calculations (see next section). Remaining plants were arranged in six blocks with one replicate per treatment per block. Nutrient treatments were initiated at this time. Water stress was initiated gradually $6 \mathrm{wk}$ after production of first true leaves to simulate more appropriately the field patterns of water stress. Volumetric soil water content (SWC) was measured every $3 \mathrm{~d}$ on all pots with a soil moisture probe (HydroSense, Campbell Scientific, Logan Utah, USA). Well-watered plants were maintained at field capacity $(\approx 22-25 \%$ SWC), whereas droughted plants were allowed to dry down to a SWC of $\approx 8 \%$. When droughted plants reached this threshold, pots were watered back to field capacity and allowed to dry down through another drought cycle. On average, drought cycles spanned $5 \mathrm{~d}$ through the 65-d experiment; therefore, most droughted plants experienced a total of 12 drought cycles. 
Growth and allocation-To assess relative growth rate and its components, whole plants were harvested, separating leaf, stem, and root material. Roots were separated from soil by washing them over a fine mesh screen. Leaves were scanned on a flatbed scanner, and leaf area was measured using the image analysis program WIN RHIZO (Regents Instruments, Quebec, Canada). All plant material was dried in an oven at $65^{\circ} \mathrm{C}$ and then weighed. Relative growth rate (RGR), net assimilation rate (NAR), leaf area ratio (LAR), specific leaf area (SLA), and leaf mass ratio (LMR) were calculated by using data from the initial and final harvests. Calculations of means, SE, and 95\% confidence intervals followed Causton and Venus (1981) for ungraded and unpaired harvests. Root mass ratio (RMR) was calculated as the proportion of total biomass allocated to roots. For statistical comparisons, RGR was calculated as ln (final biomass per replicate) $-\ln$ (mean initial biomass per species)/65 d (duration of time between the initial and final harvests).

Water potential and gas exchange-We assessed midday water potential with a Scholander-type pressure bomb, following accepted procedures to minimize transpirational water loss. Samples were cut just before measurement and were placed in plastic bags on ice in a cooler until measurement. Leaf gas exchange, including photosynthetic assimilation and stomatal conductance, was measured with a LI-COR 6400 Portable Photosynthesis and Fluorescence System (LI-COR Biosciences, Lincoln, Nebraska, USA) with ambient sunlight as the light source (average PAR inside the chamber $>1000 \mu \mathrm{mol} \cdot \mathrm{m}^{-2} \cdot \mathrm{s}^{-1}$ ). $\mathrm{CO}_{2}$ concentration inside the chamber was set to $400 \mu \mathrm{mol} \cdot \mathrm{mol}^{-1}$ and flow rates were set to $400 \mu \mathrm{mol} \cdot \mathrm{s}^{-1}$. Measurements were not recorded until conditions had equilibrated inside the chamber. Three subsample measurements were made on each leaf; these subsamples were averaged before statistical analysis. Water-use efficiency (WUE) was defined as photosynthetic assimilation (A) divided by stomatal conductance $\left(\mu \mathrm{mol} \mathrm{CO} 2 \cdot \mathrm{mol}^{-1} \mathrm{H}_{2} \mathrm{O}\right)$.

Nitrogen allocation and conservation-Nitrogen allocation and conservation traits were measured as green leaf, senesced leaf, and stem and root $\mathrm{N}$ concentrations and pool sizes; instantaneous photosynthetic nitrogen use efficiency (PNUE); and nitrogen productivity (NP). Tissue N concentration was measured on finely ground tissue by using micro Dumas combustion on a $\mathrm{CN}$ analyzer (Costech Analytical, Valencia, California, USA). Instantaneous photosynthetic nitrogen use efficiency (PNUE) was defined as photosynthetic assimilation rate per unit $\mathrm{N}\left(\mu \mathrm{mol} \mathrm{CO}_{2} \cdot \mathrm{mol}^{-1} \mathrm{~N} \cdot \mathrm{s}^{-1}\right)$. Nitrogen productivity $(\mathrm{NP})$ was defined as RGR divided by whole-plant nutrient concentration in plant tissue (PNC). PNC was calculated as a weighted average of leaf, stem, and root $\mathrm{N}$ concentration, with $\mathrm{N}$ concentrations weighted by biomass allocation to each organ. Typically, higher growth is associated with greater NP because of high $\mathrm{N}$ investment in photosynthetic tissues and lower respiration rates (Lambers et al., 2008)

Statistical analysis-Given the number of dependent variables measured, the number of comparisons to be made, and the potential correlated responses among variables, we used multivariate analysis of variance (MANOVA) to test for treatment effects on our functional trait variables (following Scheiner, 2001). The main effects included $\mathrm{N}$, water (W), functional group (perennial grass, invasive forb, native forb; this categorization allows for both differences in morphology and origin to be assessed), and block. The interactive effects included $\mathrm{N} \times \mathrm{W}, \mathrm{N} \times$ functional group, $\mathrm{W} \times$ functional group, and $\mathrm{N} \times \mathrm{W} \times$ functional group. With MANOVA, the power of the test decreases with the number of response variables included; additionally, interpretation becomes increasingly complex as more response variables are included. Thus, Scheiner (2001) recommends constructing MANOVA models around specific hypotheses regarding the response variables. Therefore, three MANOVAs were run. The first assessed growth and allocation responses, including the response variables of total biomass, root mass ratio, RGR, and SLA. The second MANOVA assessed responses of instantaneous physiological rates, including the response variables A, WUE, and midday water potential. The third MANOVA included those variables related to nutrient allocation and conservation (green leaf $\mathrm{N}$, senesced leaf N, PNUE, and NP). Four linear contrasts following each MANOVA were used to assess how native species (native forbs and perennials grasses) and invasive species differed in their responses at (1) high $\mathrm{N}$, high water; (2) high N, low water; (3) low N, high water; and (4) low N, low water. For each MANOVA model, Roy's greatest root was used to assess the significance of the MANOVA models because of its power and interpretability, as it is based on the first eigenvalue (Scheiner, 2001). Additionally, for each MANOVA model, we present the standardized canonical coefficients for the first canonical variate. These values indicate which response variables drive differences among the predictor variables as well as the correlation among the included response variables. The magnitude of the standardized canonical coefficients indicates which response variables explain the greatest (or least) variation among the predictor variables, and differences in sign among these values indicate correlations among response variables (Scheiner, 2001).

Principal components analysis (PCA) was used to (1) understand which traits most strongly influenced differences among species and treatments; (2) investigate how traits related to one another in their direction of response; and (3) indicate whether the responses were species or functional group specific. Principal components analysis is a multivariate analysis method that ordinates samples on the basis of linear combinations of their associated treatment variables. The output, expressed as a bivariate ordination plot, enables visualization of relationships between traits, treatments, species, and functional groups. In this case, the means of the unique species by treatment combinations were the samples, and the response variables were the treatment variables. As some measured variables were strongly correlated (e.g., A and PNUE; green leaf $\mathrm{N}$ and $\mathrm{NP}$ ), only one of the correlated variables was used in the analysis. The following variables were included in the PCA: total biomass, RMR, WUE, leaf water potential, PNUE, senesced leaf N, and NP. Principal components analysis was run with Canoco for Windows 4.5 (Microcomputer Power, Ithaca, NY, USA).

To assess functional trait plasticity, we assessed species-level trait plasticity, as opposed to genotype-level trait plasticity. This approach allows for greater species- and treatment-level replication because replicates are not assigned to individual genotypes of the species (Funk, 2008). We calculated the simplified relative distance plasticity index $\left(\mathrm{RDPI}_{\mathrm{s}}\right)$ for each trait as described by Valladares et al. (2006) and Martins et al. (2009). Although many indices have been suggested to assess phenotypic plasticity, with this index, values between treatment combinations can be considered as replicates and compared statistically. To calculate the replicate RDPI $_{\mathrm{s}}$ values for each species, we used the mean trait values for each of the six treatment combinations. The average value of the RDPI for each species, then, was calculated as follows:

\section{RDPIs =}

$\sum\left(\frac{\text { Distance among mean values for each species by treatment comparison }}{\text { Sum of mean values for each species by treatment comparison }}\right) / n$.

where $\mathrm{n}$ was the total number of treatment comparisons (in our case six unique comparisons of water and $\mathrm{N}$ level). Values for this index vary from 0 (no plasticity) to 1 (maximal plasticity). The replicate values were compared using a MANOVA with functional group as the main effect followed by a linear contrast comparing native and invasive species. Three MANOVA models were constructed to compare the RDPIs, similar to the models constructed for the functional traits. All MANOVA models and multivariate contrasts were analyzed using SAS v. 9.2 (SAS Institute, Cary, NY, USA).

\section{RESULTS}

Growth and biomass allocation-All factors included in the MANOVA model significantly affected growth and biomass allocation except for the three-way interaction of $\mathrm{N} \times \mathrm{W} \times$ functional group (Table 1A; Fig. 1). For all factors, significant differences among treatments were driven most strongly by changes in total biomass (Table 1B), with total biomass tending to increase with higher resource availability (Fig. 1A). In general, water availability affected the ability of plants to respond to $\mathrm{N}$ availability, as indicated by the significant $\mathrm{N} \times \mathrm{W}$ interaction (Table 1A). Across all treatments, RMR was negatively correlated with total biomass, with RMR tending to increase as total biomass decreased (Table 1B, Fig. 1B). Relationships between RGR and total biomass were more complex, being positively correlated for some treatments (e.g., $\mathrm{N}$ ) and negatively correlated for others (e.g., water) (Table 1B). Although both total biomass and RGR tended to decline with $\mathrm{N}$ availability, RGR was similar, when averaged across water treatments, but total biomass tended to be reduced under low water (Fig. 1C). In most cases, SLA was positively correlated with total biomass (Table 1B), with plants with thinner leaves tending to have greater biomass (Fig. 1D). 
TABLE 1. Statistical analysis of growth and allocation traits. (A) Overall multivariate analysis of variance (MANOVA) results for growth and biomass allocation traits, including total biomass, root mass ratio (RMR), relative growth rate (RGR), and specific leaf area (SLA). Significant factors are in bold. (B) Standardized canonical coefficients are presented to indicate the amount of variation described by each response variable in the model presented. (C) Roy's greatest root for specified linear contrasts indicates differences among native and invasive species at specific resource availabilities. Degrees of freedom for both the numerator (dfn) and denominator (dfd) are presented.

(A) Overall MANOVA: Roy's greatest root

\begin{tabular}{lrrrrc} 
Source & Value & $F$ & dfn & dfd & $P$ \\
\hline $\mathbf{N}$ & $\mathbf{1 . 3 1 7}$ & $\mathbf{6 2 . 5 8}$ & $\mathbf{4}$ & $\mathbf{1 9 0}$ & $<\mathbf{0 . 0 0 0 1}$ \\
$\mathbf{W}$ & $\mathbf{0 . 3 8 7}$ & $\mathbf{1 8 . 4 0}$ & $\mathbf{4}$ & $\mathbf{1 9 0}$ & $<\mathbf{0 . 0 0 0 1}$ \\
Functional group & $\mathbf{0 . 4 7 9}$ & $\mathbf{2 2 . 8 8}$ & $\mathbf{4}$ & $\mathbf{1 9 1}$ & $<\mathbf{0 . 0 0 0 1}$ \\
Block & $\mathbf{0 . 1 4 5}$ & $\mathbf{5 . 6 1}$ & $\mathbf{5}$ & $\mathbf{1 9 3}$ & $<\mathbf{0 . 0 0 0 1}$ \\
$\mathbf{N} \times \mathbf{W}$ & $\mathbf{0 . 1 4 2}$ & $\mathbf{6 . 7 3}$ & $\mathbf{4}$ & $\mathbf{1 9 0}$ & $<\mathbf{0 . 0 0 0 1}$ \\
$\mathbf{N} \times$ functional group & $\mathbf{0 . 0 8 7}$ & $\mathbf{4 . 1 5}$ & $\mathbf{4}$ & $\mathbf{1 9 1}$ & $\mathbf{0 . 0 0 3}$ \\
$\mathbf{W} \times$ functional group & $\mathbf{0 . 0 7 7}$ & $\mathbf{3 . 6 7}$ & $\mathbf{4}$ & $\mathbf{1 9 1}$ & $\mathbf{0 . 0 0 7}$ \\
$\mathrm{N} \times \mathrm{W} \times$ functional group & 0.047 & 2.23 & 4 & 191 & 0.067
\end{tabular}

(B) Overall MANOVA: Standardized canonical coefficients

\begin{tabular}{lccrc} 
Source & $\begin{array}{c}\text { Total } \\
\text { biomass }\end{array}$ & RMR & \multicolumn{1}{c}{ RGR } & SLA \\
\hline $\mathrm{N}$ & 1.328 & -0.548 & 0.327 & 0.338 \\
$\mathrm{~W}$ & 1.733 & -0.700 & -0.254 & 0.608 \\
Functional group & 1.737 & -0.374 & -1.486 & 0.896 \\
$\mathrm{Block}$ & 1.312 & -0.978 & -0.551 & 0.883 \\
$\mathrm{~N} \times \mathrm{W}$ & 1.916 & -0.054 & -0.576 & 0.456 \\
$\mathrm{~N} \times$ functional group & 1.170 & -0.420 & 0.522 & 0.308 \\
$\mathrm{~W} \times$ functional group & 1.537 & -0.188 & -0.325 & 0.996 \\
$\mathrm{~N} \times \mathrm{W} \times$ functional group & 0.989 & -0.325 & 0.571 & -0.140
\end{tabular}

(C) Linear contrasts: Roy's greatest root

Contrast: Native vs.

\begin{tabular}{lcrcrr}
\multicolumn{1}{c}{ invasive species } & Value & \multicolumn{1}{c}{$F$} & dfn & dfd & \multicolumn{1}{c}{$P$} \\
\hline High N, high water & 0.135 & 6.41 & 4 & 190 & $<0.0001$ \\
High N, low water & 0.119 & 5.64 & 4 & 190 & 0.0003 \\
Low N, high water & 0.219 & 10.38 & 4 & 190 & $<0.0001$ \\
Low N, low water & 0.084 & 4.01 & 4 & 190 & 0.0038 \\
\hline
\end{tabular}

For all four contrasts, significant differences existed among native and invasive species (Table 1C). At high $\mathrm{N}$ and water availability, native species tended to have lower values for most growth-related traits than did invasive species (i.e., total biomass, RMR, and SLA). At high N, low water availability, the trend was reversed, with native species having equivalent or slightly higher values for total biomass, RMR, and RGR; only SLA tended to be higher for the invasive species at high $\mathrm{N}$, low water availability. Similar patterns were observed at low N, high water, with invasive species tending to have higher values than native species for most growth-related traits (i.e., biomass, RMR, and SLA). At low N, low water availability, invasive species tended to have higher biomass and higher SLA, but native species tended to have slightly higher RGR and RMR.

Water potential, photosynthetic rate, and water-use efficiency-Nitrogen availability, water availability, functional group, and the interaction of $\mathrm{N}$ and water all significantly affected water potential, photosynthetic rate, and water-use efficiency (Table 2A, Fig. 2). All other effects were not significant. For all predictor variables, water potential and WUE were inversely correlated with photosynthetic rate (Table 2B); as water potential became increasingly negative and plants became more water-use efficient, photosynthetic rate declined (Fig. 2A-C). The responses to $\mathrm{N}$ and the interaction of $\mathrm{N}$ and water were most strongly driven by WUE, with slightly higher WUE at higher $\mathrm{N}$ availability; additionally, WUE tended to be greater under the combination of high $\mathrm{N}$ and low water than low $\mathrm{N}$ and low water availability (Fig. 2B). In contrast, the responses to water availability and functional group were most strongly driven by water potential (Table 2B). Plants grown at low water availability tended to have lower water potentials than plants grown at high water availability, and perennial grasses tended to operate at lower water potentials than the forbs (Fig. 2C).

In general, native and invasive species responded similarly to changes in resource availability with respect to water potential, photosynthetic rate, and WUE (Table 2C). Only the contrast comparing native and invasive species at low $\mathrm{N}$, high water was marginally significant. Native species tended to operate at lower water potentials and higher WUE than invasive species in this treatment combination, but invasive species tended to maintain higher photosynthetic rates.

Nitrogen allocation and conservation-Traits related to $\mathrm{N}$ allocation and conservation were significantly affected by $\mathrm{N}$, water, functional group, $\mathrm{N} \times \mathrm{W}$, and $\mathrm{N} \times$ functional group; all other factors were not significant (Table 3A, Fig. 3). Differences in NP described the greatest proportion of the variation in traits due to $\mathrm{N}$, functional group, $\mathrm{N} \times \mathrm{W}$, and $\mathrm{N} \times$ functional group (Table 3B). There was a trend for lower NP with reduced $\mathrm{N}$ and water availability, with NP 1.5- to 2.5-fold higher under high $\mathrm{N}$, high water availability compared with all other treatments in most species (Fig. 3A). Differences in PNUE described the greatest proportion of the variation in traits due to water availability (Table 3B), with PNUE declining 1.9-fold under low water availability (Fig. 3B). Overall, green and senesced leaf $\mathrm{N}$ tended to be higher under lower $\mathrm{N}$ and water availability (Fig. 3C-D),

Few differences were observed between native and invasive species for $\mathrm{N}$ allocation and conservation traits (Table $3 \mathrm{C}$ ). The only significant contrast was comparing native and invasive species at high $\mathrm{N}$, low water availability. Native species tended to have higher green leaf $\mathrm{N}$ and NP than invasive species but lower PNUE and senesced leaf $\mathrm{N}$ than invasive species under this treatment (Fig. 3A-D).

Nitrogen pool data indicate that both $\mathrm{N}$ and water availability influenced $\mathrm{N}$ pool size in most species (Fig. 4). In general, plants grown at high $\mathrm{N}$ tended to have greater total $\mathrm{N}$ pools than plants grown at lower $\mathrm{N}$. However, water availability limited $\mathrm{N}$ pool size, even under high $\mathrm{N}$ conditions. Thus, although green leaf $\mathrm{N}$ tended to increase at lower water availability, the decrease in biomass at lower water availability limited total $\mathrm{N}$ pool size. Roots and green leaves accounted for the majority of the total $\mathrm{N}$ pool across treatments. However, as resource availability decreased, root $\mathrm{N}$ pools accounted for a greater proportion of the total $\mathrm{N}$ pool. These changes in root $\mathrm{N}$ pool can be linked to increased root biomass allocation under resource-poor conditions.

Relationships among functional traits, species, and resource availability - In general, the average species scores were arranged along the first axis with respect to soil water availability; this axis explained $80.0 \%$ of the variation in the data. Samples associated with high water availability were located on the left side of the first axis, and samples associated with low water availability were located on the right side of the first axis (Fig. 5 ). Thus, plants grown at high water availability were associated 

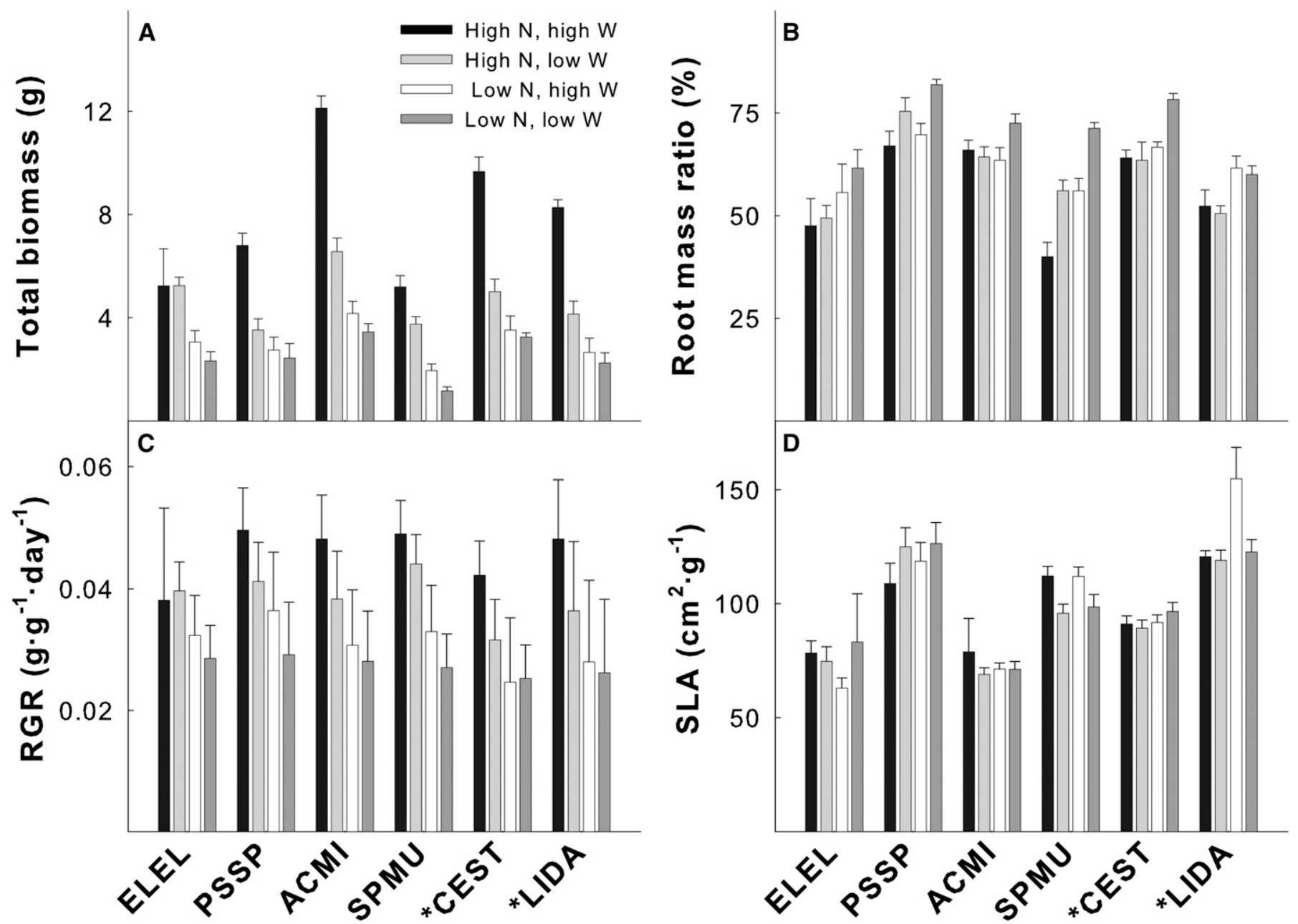

Fig. 1. Growth and allocation traits of native and invasive perennial species, including (A) total biomass, (B) root mass ratio, (C) relative growth rate (RGR), and (D) specific leaf area (SLA). Data are means \pm SE $(N=8-9)$. Figure abbreviations: ELEL, Elymus elymoides; PSSP, Pseudoroegneria spicata; ACMI, Achillea millefolium; SPMU, Sphaeralcea munroana; CEST, Centaurea stoebe; LIDA, Linaria dalmatica. Invasive species are indicated by an asterisk preceding the species abbreviation.

with higher PNUE, NP, and total biomass. In contrast, plants grown at low water availability were associated with higher senesced leaf N, more negative water potentials, greater WUE, and greater RMR. The second axis explained $12.6 \%$ of the variation in the data and was most strongly associated with RMR. This axis was associated with neither $\mathrm{N}$ nor water availability. Although some diffuse grouping could be observed for some species (e.g., S. munroana and P. spicata), neither axis was associated with either morphology or origin, with strong overlap in trait responses between native and invasive species, as well as among perennial grasses and perennial forbs.

Plasticity in functional traits-As assessed by RDPIs, plasticity did not differ between native and invasive species for the suite of growth and allocation traits measured $\left(F_{4,30}=0.60, P=\right.$ $0.66)$. Of the four traits, total biomass was the most plastic, with RDPIs ranging from $0.24-0.39$ (Table 4). Relative growth rate varied little across $\mathrm{N}$ and water availability, and RMR and SLA were fairly constant across treatments, with mean RDPI values as low as 0.01 calculated for SLA (Table 4A). Overall, SLA was the least plastic in response to variation in resource availability of the 11 traits evaluated.
In contrast, plasticity values for water potential, photosynthetic rate, and WUE were significantly different between native and invasive species $\left(F_{3,31}=5.12, P=0.005\right)$. Across all three traits, invasive species were significantly more plastic than native species. Of all the functional traits measured, photosynthetic rate was the most plastic in response to variation in resource availability (Table 4B).

Additionally, a marginally significant difference in plasticity was found between native and invasive species for traits related to $\mathrm{N}$ allocation and conservation $\left(F_{4,30}=2.73, P=0.048\right)$. Although plasticity values for senesced leaf $\mathrm{N}$ and PNUE were similar between native and invasive species, plasticity in green leaf $\mathrm{N}$ and NP was greater for invasive compared with native species (Table 4C).

\section{DISCUSSION}

In partial support of our first hypothesis, invasive species achieved greater biomass than native species under both low and high $\mathrm{N}$, when water supply was high. For example, at high $\mathrm{N}$, high water availability, invasive species had higher biomass than 
TABLE 2. Statistical analysis of water potential and gas exchange traits. (A) Overall multivariate analysis of variance (MANOVA) results for water potential $\left(\Psi_{\mathrm{w}}\right)$, photosynthetic rate $(\mathrm{A})$, and water-use efficiency (WUE). Significant factors are in bold. (B) Standardized canonical coefficients are presented to indicate the amount of variation described by each response variable in the model presented. (C) Roy's greatest root for specified linear contrasts indicates differences among native and invasive species at specific resource availabilities. Degrees of freedom for both the numerator (dfn) and denominator (dfd) are presented.

(A) Overall MANOVA: Roy's greatest root

\begin{tabular}{lccccc} 
Source & Value & $F$ & dfn & dfd & $P$ \\
\hline $\mathbf{N}$ & $\mathbf{0 . 1 2 6}$ & $\mathbf{5 . 0 7}$ & $\mathbf{3}$ & $\mathbf{1 2 1}$ & $\mathbf{0 . 0 0 2}$ \\
$\mathbf{W}$ & $\mathbf{1 . 8 3 6}$ & $\mathbf{7 4 . 0 7}$ & $\mathbf{3}$ & $\mathbf{1 2 1}$ & $<\mathbf{0 . 0 0 0 1}$ \\
Functional group & $\mathbf{0 . 4 4 2}$ & $\mathbf{1 7 . 9 6}$ & $\mathbf{3}$ & $\mathbf{1 2 2}$ & $<\mathbf{0 . 0 0 0 1}$ \\
Block & 0.075 & 1.85 & 5 & 123 & 0.109 \\
$\mathbf{N} \times \mathbf{W}$ & $\mathbf{0 . 1 6 7}$ & $\mathbf{6 . 7 2}$ & $\mathbf{3}$ & $\mathbf{1 2 1}$ & $\mathbf{0 . 0 0 0 3}$ \\
$\mathbf{N} \times$ functional group & 0.04 & 1.61 & 3 & 122 & 0.190 \\
$\mathrm{~W} \times$ functional group & 0.058 & 2.35 & 3 & 122 & 0.076 \\
$\mathbf{N} \times \mathrm{W} \times$ functional group & 0.019 & 0.78 & 3 & 122 & 0.507
\end{tabular}

(B) Overall MANOVA: Standardized canonical coefficients

\begin{tabular}{lcrc} 
Source & $\Psi_{\mathrm{w}}$ & $\mathrm{A}$ & WUE \\
\hline $\mathrm{N}$ & 0.486 & -0.513 & 1.110 \\
$\mathrm{~W}$ & 0.811 & -0.630 & 0.771 \\
Functional group & 0.981 & -0.228 & 0.841 \\
$\mathrm{Block}$ & 0.379 & -0.710 & 1.033 \\
$\mathrm{~N} \times \mathrm{W}$ & 0.593 & -0.627 & 0.968 \\
$\mathrm{~N} \times$ functional group & 0.430 & 1.224 & 0.059 \\
$\mathrm{~W} \times$ functional group & 0.918 & 0.534 & 0.809 \\
$\mathrm{~N} \times \mathrm{W} \times$ functional group & 0.142 & 0.603 & 1.183
\end{tabular}

(C) Linear contrasts: Roy's greatest root

Contrast: Native vs.

\begin{tabular}{lccccc}
\multicolumn{1}{c}{ invasive species } & Value & $F$ & dfn & dfd & $P$ \\
\hline High N, high water & 0.025 & 1.01 & 3 & 121 & 0.390 \\
High N, low water & 0.025 & 1.01 & 3 & 121 & 0.390 \\
Low N, high water & 0.068 & 2.74 & 3 & 121 & 0.046 \\
Low N, low water & 0.047 & 1.88 & 3 & 121 & 0.136
\end{tabular}

native species, though RGR was similar between the species groups. At high N, low water availability, natives maintained similar total biomass but a slightly higher RGR than invasive species. Thus, although biomass and RGR declined in response to decreased water availability in both native and invasive species, the species group achieving higher biomass and/or RGR under a given treatment combination depended on soil water availability. In contrast, invasive species had higher total biomass but slightly lower RGR than native species under both the low N treatments, regardless of water availability. Under all treatment combinations, invasive species had higher SLA than native species. Constructing cheaper tissues may provide invasive species a growth advantage under both low and high $\mathrm{N}$ (Lambers and Poorter, 1992) as well as under well-watered conditions (Grotkopp and Rejmanek, 2007; James and Drenovsky, 2007; James, 2008). However, under low water availability, high SLA may be disadvantageous, as it provides greater surface area for transpiration (Lambers et al., 2008). Additionally, maintaining a higher RMR than natives under both high $\mathrm{N}$, high water and low $\mathrm{N}$, high water may have provided invasives with greater access to soil nutrients (Aerts and Chapin, 2000). At lower water availability, native species invested more total biomass into roots than did invasive species. Increased allocation to roots under drought conditions is a key adaptation to maintaining plant water status
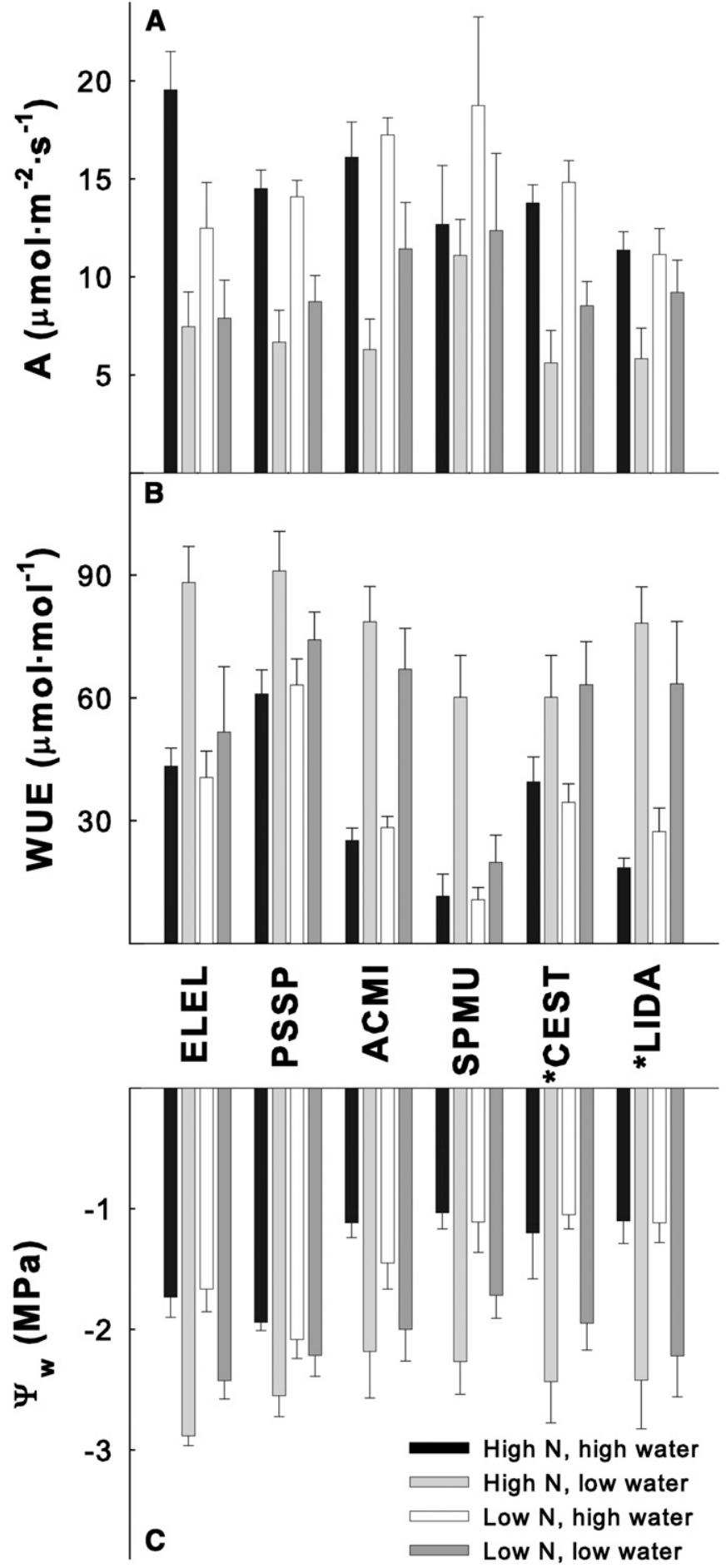

Fig. 2. Gas exchange and water potential traits of native and invasive perennial species, including (A) photosynthetic rate, (B) instantaneous water-use efficiency (WUE), and (C) plant water potential. Data are means $\pm \mathrm{SE}(N=5-9)$. Note: See Fig. 1 legend for definitions of abbreviations.

(Lambers et al., 2008), enabling native species to maintain greater biomass than invasive species under decreased water availability.

In contrast to our initial hypotheses, native and invasive species were similar with respect to instantaneous physiological measurements, including midday water potential, photosynthetic 
TABLE 3. Statistical analysis of nitrogen allocation and conservation traits. (A) Overall multivariate analysis of variance (MANOVA) results for nitrogen (N) allocation and conservation traits, including green leaf $\mathrm{N}$, senesced leaf $\mathrm{N}$, photosynthetic $\mathrm{N}$ use efficiency (PNUE), and nitrogen productivity (NP). Significant factors are in bold. (B) Standardized canonical coefficients are presented to indicate the amount of variation described by each response variable in the model presented. (C) Roy's greatest root for specified linear contrasts indicates differences among native and invasive species at specific resource availabilities. Degrees of freedom for both the numerator (dfn) and denominator (dfd) are presented.

\begin{tabular}{|c|c|c|c|c|c|}
\hline \multicolumn{6}{|c|}{ A. Overall MANOVA: Roy's greatest root } \\
\hline Source & Value & $F$ & dfn & dfd & $P$ \\
\hline$\overline{\mathbf{N}}$ & 0.722 & 24.38 & 4 & 135 & $<0.0001$ \\
\hline W & 0.549 & 18.54 & 4 & 135 & $<0.0001$ \\
\hline Functional group & 0.250 & 8.51 & 4 & 136 & $<0.0001$ \\
\hline Block & 0.075 & 2.08 & 5 & 138 & 0.072 \\
\hline $\mathbf{N} \times \mathbf{W}$ & 0.165 & 5.56 & 4 & 135 & 0.0004 \\
\hline $\mathbf{N} \times$ functional group & 0.098 & 3.33 & 4 & 136 & 0.012 \\
\hline $\mathrm{W} \times$ functional group & 0.037 & 1.25 & 4 & 136 & 0.294 \\
\hline $\mathrm{N} \times \mathrm{W} \times$ functional group & 0.045 & 1.53 & 4 & 136 & 0.198 \\
\hline \multicolumn{6}{|c|}{ B. Standardized canonical coefficients } \\
\hline Source & $\begin{array}{l}\text { Green } \\
\text { leaf } N\end{array}$ & $\begin{array}{l}\text { Senesced } \\
\text { leaf } \mathrm{N}\end{array}$ & PNUE & NP & \\
\hline $\mathrm{N}$ & 0.897 & 0.329 & -0.432 & 1.503 & \\
\hline $\mathrm{W}$ & 0.115 & -0.186 & 0.982 & 0.510 & \\
\hline Functional group & 1.010 & 0.481 & -0.367 & 1.038 & \\
\hline Block & -0.456 & 0.934 & 0.474 & -0.298 & \\
\hline $\mathrm{N} \times \mathrm{W}$ & -0.132 & 0.032 & 0.188 & 1.102 & \\
\hline $\mathrm{N} \times$ functional group & -0.371 & 0.304 & 0.655 & -1.304 & \\
\hline $\mathrm{W} \times$ functional group & 0.579 & -0.398 & 0.378 & 1.191 & \\
\hline $\mathrm{N} \times \mathrm{W} \times$ functional group & -0.098 & 0.660 & 0.355 & -0.941 & \\
\hline \multicolumn{6}{|l|}{ C. Roy's greatest root } \\
\hline $\begin{array}{l}\text { Contrast: Native vs. } \\
\text { invasive species }\end{array}$ & Value & $F$ & $\mathrm{dfn}$ & dfd & $P$ \\
\hline High $N$, high water & 0.044 & 1.47 & 4 & 135 & 0.215 \\
\hline High N, low water & 0.131 & 4.41 & 4 & 135 & 0.002 \\
\hline Low N, high water & 0.016 & 0.56 & 4 & 135 & 0.695 \\
\hline Low N, low water & 0.049 & 1.65 & 4 & 135 & 0.166 \\
\hline
\end{tabular}

rates, and WUE. Midday water potential became increasingly negative, and photosynthetic rates declined in the low-water treatments. In contrast, WUE efficiency increased under low water availability, driven in large part by strong declines in stomatal conductance (data not shown). Midday water potentials indicate plant water status during the most stressful portion of the day, when plants are balancing radiative heat loads with transpirational water loss. Under drought conditions, plants close or partially close their stomata to limit water losses, and as a result, photosynthetic rates decline (Casper et al., 2006). Over the long term, decreased photosynthetic rates limit carbon gain and thus the building blocks available for new biomass production. In contrast to the effects of water on midday water potential and gas exchange, the impacts of decreased $\mathrm{N}$ availability were more muted and were driven in large part by impacts on WUE, with WUE increasing with greater $\mathrm{N}$ availability. Greater WUE can come at the cost of greater $\mathrm{N}$ requirements because of increased $\mathrm{N}$ investment in photosynthetic machinery (Wright et al., 2001, 2003) and thus lower PNUE (Martin et al., 2010). In support, we observed higher green leaf $\mathrm{N}$, lower PNUE, and higher WUE in plants grown at high $\mathrm{N}$, low water than at high $\mathrm{N}$, high water.

Likewise, $\mathrm{N}$ allocation and conservation traits were similar among our suite of native and invasive species. Nitrogen pro- ductivity and PNUE were the most important drivers of trait relationships under changing resource availabilities. Nitrogen productivity was highest at high $\mathrm{N}$, high water and significantly reduced under all other treatments. Fast-growing plants with high $\mathrm{N}$ allocation to photosynthetic tissues typically have higher NP. As more biomass is invested in nonphotosynthetic tissues (e.g., greater RMR at low resource availabilities), NP declines (Lambers et al., 2008). As described previously, PNUE is inversely correlated with WUE and thus declined with decreased soil water availability. Green leaf $\mathrm{N}$ was low in well-watered plants, most likely because of biomass dilution. In contrast, droughted plants tended to have higher senesced leaf $\mathrm{N}$ concentrations, indicative of poorer $\mathrm{N}$ resorption proficiency. The process of resorption requires translocation of nutrients to storage tissues, which can be negatively affected by low soil water availability (Wright and Westoby, 2003; Renteria and Jaramillo, 2011). Overall, five of the six species achieved complete resorption ( $<7 \mathrm{~g} \cdot \mathrm{kg}^{-1} \mathrm{~N}$; sensu Killingbeck, 1996) under at least one treatment combination, with two species ( $S$. munroana and $C$. stoebe) being highly proficient under all treatments. Previous greenhouse work with $C$. stoebe indicated its high $\mathrm{N}$-use efficiency is linked to a long mean retention time, which depends in part on proficient resorption (D'Imperio, 2005). All species showed similar $\mathrm{N}$ allocation patterns, with root $\mathrm{N}$ pools becoming increasingly dominant in terms of whole-plant $\mathrm{N}$ budgets as resource availability declined. These changes were more strongly driven by changes in biomass allocation patterns (i.e., increased RMR with decreased resource availability) than by changes in tissue nutrient concentrations. These data stress the importance of nonphotosynthetic tissues to whole-plant nutrient budgets and the need to look beyond leaf traits when studying $\mathrm{N}$ conservation mechanisms.

From our data, it is evident that limited water availability constrained responses to $\mathrm{N}$ availability, and overall, soil water availability was the major driver of plant traits, as evidenced by the PCA. For example, drought limited total biomass production, even in the high $\mathrm{N}$ treatment. Drought also had strong impacts on traits related to $\mathrm{N}$ allocation and conservation, limiting $\mathrm{N}$ resorption, decreasing instantaneous PNUE, and reducing NP. Drought limits plant access to soil $\mathrm{N}$, by affecting soil biological and physical processes that influence soil $\mathrm{N}$ supply and plant physiological processes that influence plant $\mathrm{N}$ uptake. In dry soils, soil microbial activity is reduced, limiting decomposition and mineralization (Burke, 1989). Of greater importance in this greenhouse study, drought limits nutrient supply to roots by decreasing $\mathrm{N}$ movement through soils via diffusion or mass flow (Dunham and Nye, 1973). As soils dry, diffusion rates decrease because of reduced nutrient mobility in the soil, and reduced transpiration rates limit nutrient mass flow rates through soil, both of which reduce plant nutrient uptake (Lambers et al., 2008).

Many authors have argued that high $\mathrm{N}$ availability favors invasive species and that low $\mathrm{N}$ availability favors native species. However, evidence is mounting that invasive species are successful under resource-limiting conditions (e.g., Funk and Vitousek, 2007; James et al., 2011). Most work in this area has focused on the role of resource uptake and use (e.g., Drenovsky et al., 2008), but many of the traits associated with success in low-resource environments are those related to resource conservation and storage (Berendse, 1994; Aerts, 1999). Although many authors have measured soft traits, like SLA, that correspond to leaf longevity, they are only a proxy for resource conservation potential. In this study, invasive species had higher SLA, but native and invasive species had very similar $\mathrm{N}$ allocation 


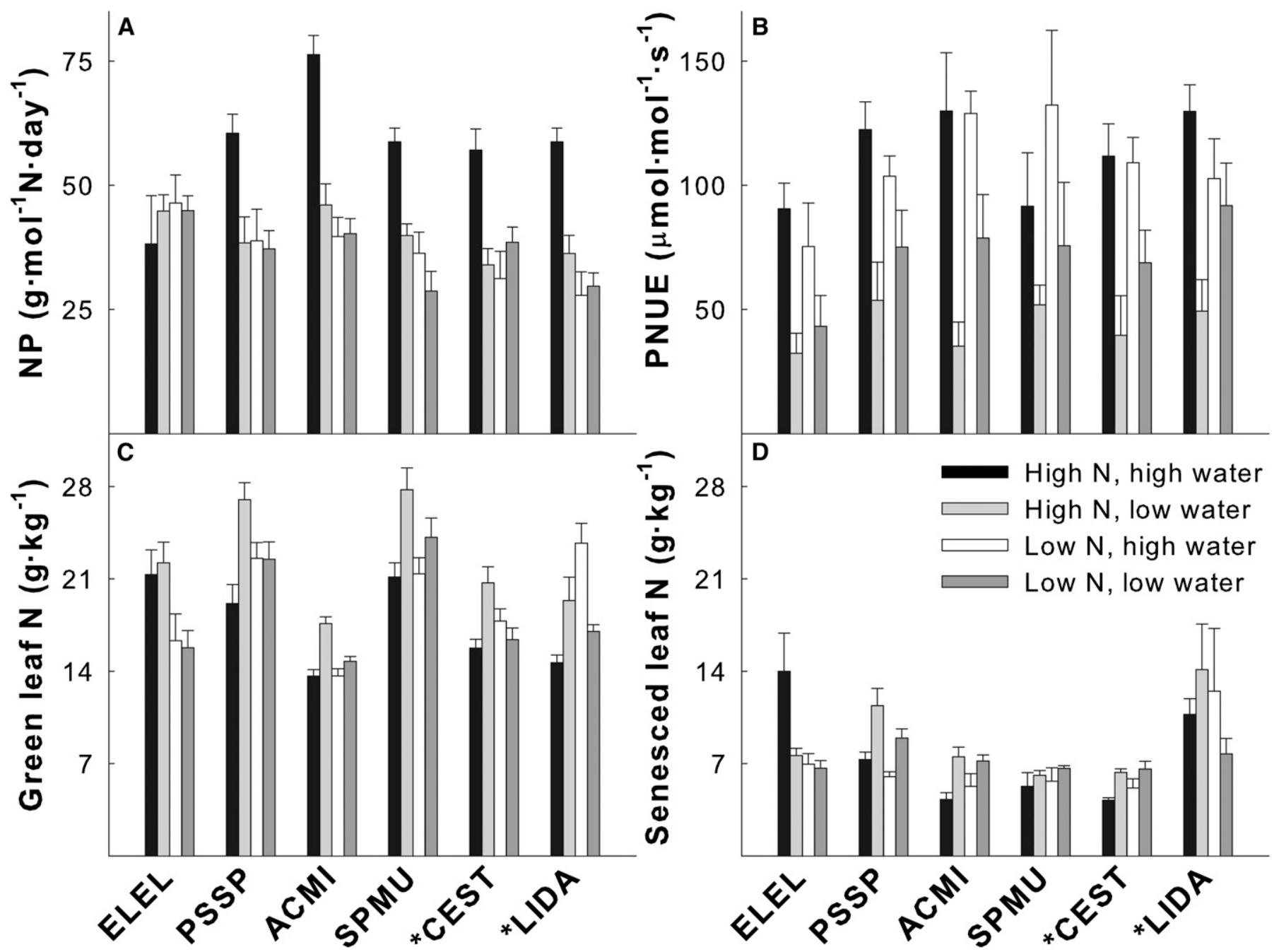

Fig. 3. Nitrogen $(\mathrm{N})$ allocation and conservation traits of native and invasive perennial species, including (A) N productivity (NP), (B) photosynthetic $\mathrm{N}$ use efficiency (PNUE), (C) green leaf N, and (D) senesced leaf N. Data are means \pm SE $(N=2-9)$. Note: See Fig. 1 legend for definitions of abbreviations.

and conservation patterns. Plants with higher PNUE and lower senesced leaf $\mathrm{N}$ (and thus greater resorption proficiency, sensu Killingbeck, 1996) had enhanced plant performance, as assessed by total plant biomass, at the end of the experiment $(P \leq$ 0.005 for both variables; data not shown). These correlations stress the importance of resource conservation traits for the success of invasive species in resource-poor systems, and further research and emphasis should be placed on these traits in invasive species. Without data on traits such as nutrient-use efficiency, mean retention time, resorption, and storage, we will fail to recognize key mechanisms supporting the role of invasive species in resource-poor environments.

Contrary to expectations, native and invasive species were similarly plastic for most measured traits. The greatest differences in plasticity between native and invasive species were observed for instantaneous measurements (A, WUE, and plant water potential), with invasive species being more plastic in response to resource availability for all three traits. Although there was a marginally significant difference in plasticity for $\mathrm{N}$ allocation and conservation traits, no difference in plasticity existed between native and invasive spe- cies for growth and allocation traits. These results are similar to those of a study comparing related species of invasive and native woody vines, in which native and invasive species had similar plasticity for 14 out of 17 physiological and growth traits measured, though overall plasticity was greater in invasive than in native species (Osunkoya et al., 2010). Likewise, in two phylogenetically paired studies of native and invasive species across a range of life forms, native and invasive species did not differ in their plasticity for a suite of growth and physiological traits (Funk, 2008; Godoy et al., 2011). These studies suggest plasticity alone may not predict the success of invasive species. Finally, plasticity varied greatly depending on the trait measured and was not consistent among the trait groupings. The most plastic traits generally were those that require only small changes in allocation of resources or functioning and/or are fairly reversible, such as photosynthetic rate, PNUE, total biomass, and NP. In contrast, those traits that require (or are strongly influenced by) more long-term changes in tissue construction were less plastic, such as RGR, SLA, green leaf N, and senesced leaf N, which were the least plastic traits. 


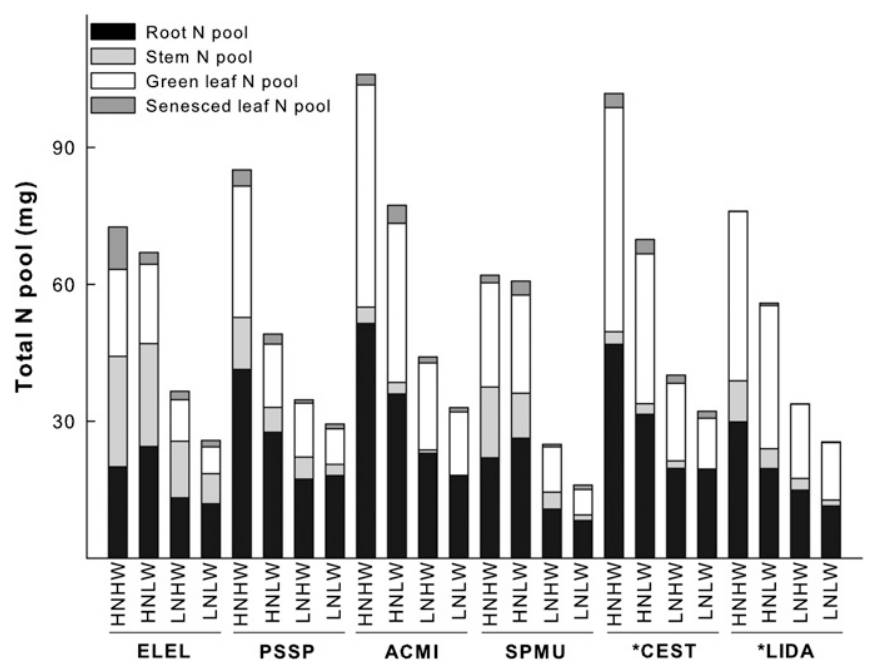

Fig. 4. Total nitrogen $(\mathrm{N})$ pools of native and invasive perennial species grown at two $\mathrm{N}$ levels and two water levels. Total $\mathrm{N}$ pools are composed of root, stem, green leaf, and senesced leaf $\mathrm{N}$ pools. Treatment codes are as follows: HNHW, high N, high water; HNLW, high N, low water; LNHW, low N, high water; LNLW, low N, low water. Data are means $(N=$ 7-9). Note: See Fig. 1 legend for definitions of other abbreviations.

Multiple resource limitations constrain plant growth and plasticity and may be particularly strong drivers of plant growth and function in arid, nutrient-poor systems (Bloom et al., 1985; Gleeson and Tilman, 1992; James et al., 2005; Valladares et al., 2007). The influence of multiple resource limitations on patterns of trait convergence or divergence as well as trait plasticity among native and invasive species has direct implications for advancing theories of invasion and invasion resistance. In this study, invasives tended to have higher SLA, supporting the notion that invasive species tend to be positioned further along the leaf economics spectrum toward resource capture (Wright et al., 2004). We also found, however, strong evidence for functional similarity and plasticity between native and invasive species,

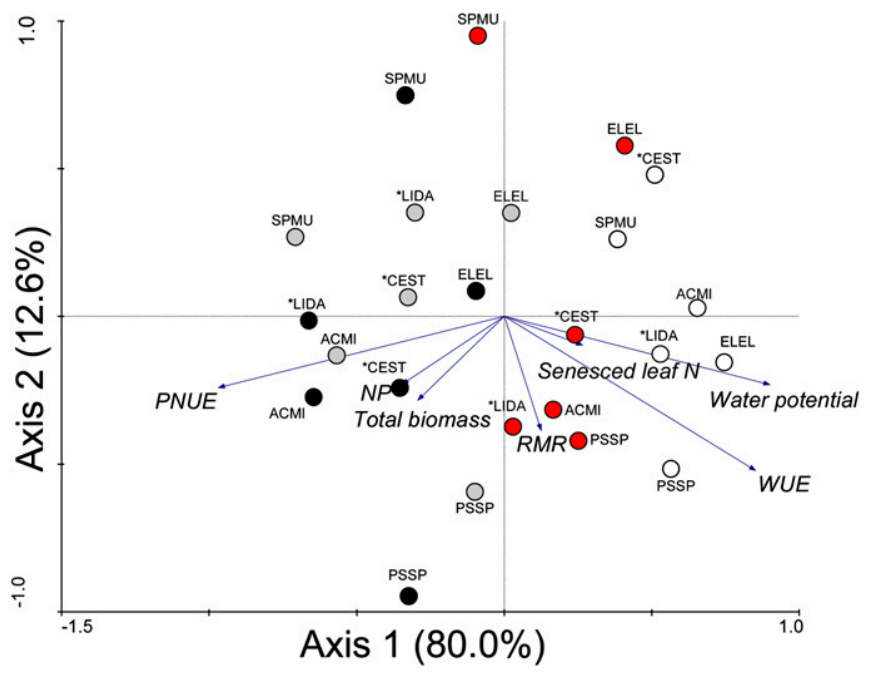

Fig. 5. Principal components analysis of species and plant functional traits. Colors represent different treatment combinations (black, HNHW; white, HNLW; gray, LNHW; red = LNLW). Note: See legends of Figs. 1 and 4 for definitions of abbreviations.
TABLE 4. Plasticity indices for measured physiological and morphological variables. Plasticity was measured according to the relative distance plasticity index, as described in Valladares et al. (2006). Data are means \pm 1 SE $(N=6)$. Note: See Tables 1-3 for definitions of abbreviations.

(A) Growth and allocation traits

\begin{tabular}{llccc} 
Species & Total biomass & \multicolumn{1}{c}{ RMR } & \multicolumn{1}{c}{ RGR } & SLA \\
\hline $\begin{array}{l}\text { Elymus elymoides } \\
\text { Pseudoroegneria }\end{array}$ & $0.24 \pm 0.06$ & $0.07 \pm 0.02$ & $0.1 \pm 0.02$ & $0.03 \pm 0.01$ \\
$\quad$ spicata & $0.26 \pm 0.07$ & $0.06 \pm 0.01$ & $0.14 \pm 0.03$ & $0.02 \pm 0.00$ \\
$\begin{array}{l}\text { Achillea millefolium } \\
\text { Sphaeralcea }\end{array}$ & $0.33 \pm 0.07$ & $0.04 \pm 0.01$ & $0.15 \pm 0.03$ & $0.01 \pm 0.00$ \\
$\quad$ munroana & $0.39 \pm 0.07$ & $0.14 \pm 0.04$ & $0.17 \pm 0.04$ & $0.02 \pm 0.01$ \\
$\begin{array}{l}\text { Centaurea stoebe } \\
\text { Linaria dalmatica }\end{array}$ & $0.28 \pm 0.07$ & $0.06 \pm 0.02$ & $0.15 \pm 0.04$ & $0.01 \pm 0.00$ \\
& $0.34 \pm 0.07$ & $0.06 \pm 0.01$ & $0.17 \pm 0.04$ & $0.03 \pm 0.01$
\end{tabular}

(B) Water potential, A, WUE

\begin{tabular}{lccc} 
Species & Water potential & A & WUE \\
\hline E. elymoides & $0.16 \pm 0.04$ & $0.56 \pm 0.12$ & $0.20 \pm 0.06$ \\
P. spicata & $0.07 \pm 0.02$ & $0.61 \pm 0.10$ & $0.11 \pm 0.03$ \\
A. millefolium & $0.19 \pm 0.04$ & $0.55 \pm 0.11$ & $0.33 \pm 0.08$ \\
S. munroana & $0.23 \pm 0.05$ & $0.49 \pm 0.11$ & $0.41 \pm 0.11$ \\
C. stoebe & $0.24 \pm 0.05$ & $0.61 \pm 0.09$ & $0.18 \pm 0.05$ \\
L. dalmatica & $0.24 \pm 0.07$ & $0.58 \pm 0.10$ & $0.39 \pm 0.08$
\end{tabular}

(C) $\mathrm{N}$ allocation and conservation

\begin{tabular}{lcccc} 
Species & Green leaf N & $\begin{array}{c}\text { Senesced } \\
\text { leaf N }\end{array}$ & PNUE & NP \\
\hline E. elymoides & $0.11 \pm 0.03$ & $0.19 \pm 0.06$ & $0.29 \pm 0.06$ & $0.20 \pm 0.06$ \\
P. spicata & $0.09 \pm 0.02$ & $0.17 \pm 0.03$ & $0.23 \pm 0.05$ & $0.11 \pm 0.03$ \\
A. millefolium & $0.07 \pm 0.02$ & $0.16 \pm 0.04$ & $0.34 \pm 0.09$ & $0.33 \pm 0.08$ \\
S. munroana & $0.08 \pm 0.02$ & $0.06 \pm 0.01$ & $0.24 \pm 0.05$ & $0.41 \pm 0.10$ \\
C. stoebe & $0.07 \pm 0.02$ & $0.13 \pm 0.03$ & $0.28 \pm 0.07$ & $0.18 \pm 0.05$ \\
L. dalmatica & $0.13 \pm 0.03$ & $0.16 \pm 0.04$ & $0.24 \pm 0.06$ & $0.39 \pm 0.08$ \\
\hline
\end{tabular}

particularly with respect to nutrient allocation and conservation traits, supporting community assembly hypotheses based on habitat filtering (Tecco et al., 2010). Importantly, our data show that multiple resource limitations influence the degree of trait convergence or divergence between invasive and native species. The limited number of species used in this study and the lack of phylogenetically controlled comparisons constrain our ability to generalize beyond our particular system. Nevertheless, these data make a strong case for improved understanding of how multiple resource and environmental stressors influence differences in resource conservation and resource capture traits between native and invasive species if we are to further advance theories of invasion and invasion resistance.

\section{LITERATURE CITED}

AERTS, R. 1996. Nutrient resorption from senescing leaves of perennials: Are there general patterns? Journal of Ecology 84: 597-608.

AERTS, R. 1999. Interspecific competition in natural plant communities: Mechanisms, trade-offs and plant-soil feedbacks. Journal of Experimental Botany 50: 29-37.

AERTS, R., AND F. S. Chapin. 2000. The mineral nutrition of wild plants revisited: A re-evaluation of processes and patterns. Advances in Ecological Research 30: 1-67.

BAKER, H. 1965. Characteristics and modes of origin of weeds. In H. G. Baker and G. L. Stebbins [eds.], Genetics of colonizing species, 147168. Academic Press, New York, New York, USA.

Berendse, F. 1994. Competition between plant populations at low and high nutrient supplies. Oikos 71: 253-260.

Bloom, A. J., F. S. Chapin, and H. A. Mooney. 1985. Resource limitation in plants-An economic analogy. Annual Review of Ecology and Systematics 16: 363-392. 
BurKe, I. C. 1989. Control of nitrogen mineralization in a sagebrush steppe landscape. Ecology 70: 1115-1126.

Casper, B. B., I. N. Forseth, And D. A. Wait. 2006. A stage-based study of drought response in Cryptantha flava (Boraginaceae): Gas exchange, water use efficiency, and whole plant performance. American Journal of Botany 93: 978-987.

Causton, D. R., and J. C. Venus. 1981. The biometry of plant growth London, United Kingdom: Edward Arnold.

Dale, M. P., and D. R. Causton. 1992. The ecophysiology of Veronica chamaedrys, $V$. montana and $V$. officinalis. 2. The interaction of irradiance and water regime. Journal of Ecology 80: 493-504.

Daleo, P., J. Alberti, and O. Iribarne. 2009. Biological invasions and the neutral theory. Diversity \& Distributions 15: 547-553.

Davidson, A. M., M. Jennions, And A. B. Nicotra. 2011. Do invasive species show higher phenotypic plasticity than native species and, if so, is it adaptive? A meta-analysis. Ecology Letters 14: 419-431.

DiAZ, S., AND M. CABIDO. 2001. Vive la difference: Plant functional diversity matters to ecosystem processes. Trends in Ecology \& Evolution 16: 646-655.

D'Imperio, E. A. 2005. Nitrogen dynamics of Centaurea maculosa and native species. M.S. thesis, Montana State University, Bozeman, Montana, USA.

Drenovsky, R. E., C. E. Martin, M. R. Falasco, and J. J. James. 2008. Variation in resource acquisition and utilization traits between native and invasive perennial forbs. American Journal of Botany 95: 681-687.

Duncan, R. P., AND P. A. Williams. 2002. Ecology-Darwin's naturalization hypothesis challenged. Nature 417: 608-609.

Dunham, R. J., AND P. H. NYE. 1973. Influence of soil-water content on uptake of ions by roots. 1. Soil-water content gradients near a plane of onion roots. Journal of Applied Ecology 10: 585-598.

Fargione, J., C. S. Brown, and D. Tilman. 2003. Community assembly and invasion: An experimental test of neutral versus niche processes. Proceedings of the National Academy of Sciences, USA 100 $8916-8920$.

FunK, J. L. 2008. Differences in plasticity between invasive and native plants from a low resource environment. Journal of Ecology 96: $1162-1173$.

Funk, J. L., AND P. M. Vitousek. 2007. Resource-use efficiency and plant invasion in low-resource systems. Nature 446: 1079-1081.

Gleeson, S. K., And D. Tilman. 1992. Plant allocation and the multiple limitation hypothesis. American Naturalist 139: 1322-1343.

Godoy, O., F. Valladares, and P. Castro-Diez. 2011. Multispecies comparison reveals that invasive and native plants differ in their traits but not in their plasticity. Functional Ecology 25: 1248-1259.

GrotKopp, E., AND M. REJMANEK. 2007. High seedling relative growth rate and specific leaf area are traits of invasive species: Phylogenetically independent contrasts of woody angiosperms. American Journal of Botany 94: 526-532.

Huenneke, L. F., S. P. Hamburg, R. Koide, H. A. Mooney, and P. M. Vitousek. 1990. Effects of soil resources on plant invasion and community structure in Californian serpentine grassland. Ecology 71: 478-491.

JAMES, J. J. 2008. Effect of soil nitrogen stress on the relative growth rate of annual and perennial grasses in the Intermountain West. Plant and Soil 310: 201-210.

James, J. J., AND R. E. DRenovsky. 2007. A basis for relative growth rate differences between native and invasive forb seedlings. Rangeland Ecology and Management 60: 395-400.

James, J. J., R. E. Drenovsky, T. A. Monaco, and M. J. Rinella. 2011. Managing soil nitrogen to restore annual grass-infested plant communities: Effective strategy or incomplete framework? Ecological Applications 21: 490-502.

James, J. J., B. S. Smith, E. A. Vasquez, and R. L. Sheley. 2010. Principles for ecologically based invasive plant management. Invasive Plant Science and Management 3: 229-239.

James, J. J., R. L. TilleR, And J. H. Richards. 2005. Multiple resources limit plant growth and function in a saline-alkaline desert community. Journal of Ecology 93: 113-126.

KillingBeCK, K. T. 1996. Nutrients in senesced leaves: Keys to the search for potential resorption and resorption proficiency. Ecology 77: $1716-1727$.
Killingbeck, K. T., And W. G. Whitford. 1996. High foliar nitrogen in desert shrubs: An important ecosystem trait or defective desert doctrine? Ecology 77: 1728-1737.

Lambers, H., F. S. Chapin, and T. L. Pons. 2008. Plant physiological ecology. Springer, New York, New York, USA.

LAMBers, H., AND H. PoORTer. 1992. Inherent variation in growth rate between higher plants-A search for physiological causes and ecological consequences. Advances in Ecological Research 23: 187-261.

Lavorel, S., and E. Garnier. 2002. Predicting changes in community composition and ecosystem functioning from plant traits: Revisiting the Holy Grail. Functional Ecology 16: 545-556.

Leishman, M. R., T. Haslehurst, A. Ares, and Z. Baruch. 2007. Leaf trait relationships of native and invasive plants: Community- and global-scale comparisons. New Phytologist 176: 635-643.

Leishman, M. R., And V. P. Thomson. 2005. Experimental evidence for the effects of additional water, nutrients and physical disturbance on invasive plants in low fertility Hawkesbury Sandstone soils, Sydney. Australian Journal of Ecology 93: 38-49.

Leishman, M. R., V. P. Thomson, And J. Cooke. 2010. Native and exotic invasive plants have fundamentally similar carbon capture strategies. Journal of Ecology 98: 28-42.

Martin, K. C., D. Bruhn, C. E. Lovelock, I. C. Feller, J. R. Evans, and M. C. BALL. 2010. Nitrogen fertilization enhances water-use efficiency in a saline environment. Plant, Cell \& Environment 33: 344-357.

Martins, P., L. Sampedro, X. Moreira, and R. Zas. 2009. Nutritional status and genetic variation in the response to nutrient availability in Pinus pinaster. A multisite field study in northwest Spain. Forest Ecology and Management 258: 1429-1436.

May, J. D., and K. T. KILlingBeCK. 1992. Effects of preventing nutrient resorption on plant fitness and foliar nutrient dynamics. Ecology 73: $1868-1878$.

Osunkoya, O. O., D. Bayliss, F. D. Panetta, and G. Vivian-Smith. 2010. Variation in ecophysiology and carbon economy of invasive and native woody vines of riparian zones in south-eastern Queensland. Austral Ecology 35: 636-649.

Ramirez-Valiente, J. A., D. Sanchez-Gomez, I. Aranda, and F. VAlladARES. 2010. Phenotypic plasticity and local adaptation in leaf ecophysiological traits of 13 contrasting cork oak populations under different water availabilities. Tree Physiology 30: 618-627.

RENTERIA, L. Y., AND V. J. JARAMILLO. 2011. Rainfall drives leaf traits and leaf nutrient resorption in a tropical dry forest in Mexico. Oecologia 165: 201-211.

Richards, C. L., O. Bossdorf, N. Z. Muth, J. Gurevitch, and M. Pigliucci. 2006. Jack of all trades, master of some? On the role of phenotypic plasticity in plant invasions. Ecology Letters 9: 981-993.

Scharfy, D., A. Funk, H. O. Venterink, and S. Gusewell. 2011. Invasive forbs differ functionally from native graminoids, but are similar to native forbs. New Phytologist 189: 818-828.

Scheepens, J. F., E. S. Frei, and J. Stocklin. 2010. Genotypic and environmental variation in specific leaf area in a widespread Alpine plant after transplantation to different altitudes. Oecologia 164: $141-150$.

SCHEINER, S. 2001. MANOVA: Multiple response variables and multispecies interactions. In S. M. Scheiner and J. Gurevitch [eds.], Design and analysis of ecological experiments, 99-115. Oxford University Press USA, New York, New York, USA

Suding, K. N., S. Lavorel, F. S. Chapin, J. H. C. Cornelissen, S. Diaz, E. GarNiER, D. GoldBerg, ET AL. 2008. Scaling environmental change through the community-level: A trait-based response-and-effect framework for plants. Global Change Biology 14: 1125-1140.

Tecco, P. A., S. Diaz, M. Cabido, and C. Urcelay. 2010. Functional traits of alien plants across contrasting climatic and land-use regimes: Do aliens join the locals or try harder than them? Journal of Ecology 98: 17-27.

Thompson, K., J. G. Hodgson, J. P. Grime, and M. J. W. Burke. 2001. Plant traits and temporal scale: Evidence from a 5-year invasion experiment using native species. Journal of Ecology 89: 1054-1060.

Thompson, K., J. G. Hodgson, And T. C. G. Rich. 1995. Native and alien invasive plants: More of the same? Ecography 18: 390-402.

Valladares, F., E. Gianoli, and J. M. Gomez. 2007. Ecological limits to plant phenotypic plasticity. New Phytologist 176: 749-763. 
Valladares, F., and R. W. Pearcy. 2002. Drought can be more critical in the shade than in the sun: A field study of carbon gain and photoinhibition in a Californian shrub during a dry El Niño year. Plant, Cell \& Environment 25: 749-759.

Valladares, F., D. Sanchez-Gomez, and M. A. Zavala. 2006. Quantitative estimation of phenotypic plasticity: Bridging the gap between the evolutionary concept and its ecological applications. Journal of Ecology 94: 1103-1116.

Van Heerwaarden, L. M., S. Toet, and R. Aerts. 2003. Nitrogen and phosphorus resorption efficiency and proficiency in six sub-arctic bog species after 4 years of nitrogen fertilization. Journal of Ecology 91: 1060-1070.

Van Kleunen, M., E. Weber, and M. Fischer. 2010. A meta-analysis of trait differences between invasive and non-invasive plant species. Ecology Letters 13: 235-245.
WeIHer, J., ANd P. Keddy. 1999. Ecological assembly rules: Perspectives, advances, retreats. Cambridge University Press, Cambridge, UK.

Wright, I. J., P. B. Reich, And M. Westoby. 2001. Strategy shifts in leaf physiology, structure and nutrient content between species of highand low-rainfall and high- and low-nutrient habitats. Functional Ecology 15: 423-434.

Wright, I. J., P. B. Reich, And M. Westoby. 2003. Least-cost input mixtures of water and nitrogen for photosynthesis. American Naturalist 161: 98-111.

Wright, I. J., P. B. Reich, M. Westoby, D. D. Ackerly, Z. Baruch, F. Bongers, J. CAVEnder-Bares, ET AL. 2004. The worldwide leaf economics spectrum. Nature 428: 821-827.

Wright, I. J., AND M. Westoby. 2003. Nutrient concentration, resorption and lifespan: Leaf traits of Australian sclerophyll species. Functional Ecology 17: 10-19. 